Volume 19 Number 2 December 2019.p. 527-546

https://doi.org/10.30603/au.v19i2.1110

\title{
Integration of Interdisciplinary scientific in the Curriculum at UIN Raden Fatah Palembang
}

\author{
Ahmad Zainuri \& K.A.Bukhori \\ UIN Raden Fatah Palembang
}

\begin{abstract}
This article designates the change of IAIN Raden Fatah Palembang into UIN substantial changes in the structure of scientific buildings (epistemology of science) therein. The construction the epistemology of science integration is then called "rumah ilmu" (the "house of science"). The concept of the paradigm is elaborated in four primary areas of a curriculum, namely the philosophical, material, methodological, and strategic domains. Concerning the current Industrial Revolution 4.0 era, the importance of the integrative-interconnected scientific paradigm at UIN Raden Fatah, which synergizes Islamic science and science-technology in the principle of monotheism, has contributed to the forming a unity of truth and unity of knowledge.
\end{abstract}

\section{Integrasi keilmuan interdisipliner pada Kurikulum di UIN Raden Fatah Palembang}

\begin{abstract}
Abstrak
Artikel ini memaparkan perubahan IAIN Raden Fatah Palembang menjadi UIN secara substansial terjadi perubahan dalam struktur bangunan keilmuan (epistemologi sains) didalamnya. Bangunan integrasi epistemologi sains yang dinamakan "rumah ilmu". Konsep paradigma tersebut dijabarkan dalam empat ranah utama sebuah kurikulum yaitu ranah filosofis, materi, metodologi dan strategi. Dalam kaitannya dengan era Revolusi Industri 4.0 saat ini pentingnya paradigma integratif-interkonektif keilmuan di UIN Raden Fatah yang mensinergikan ilmu keislaman dan ilmu pengetahuan-teknologi dalam prinsip tauhid, sehingga membentuk kesatuan kebenaran dan kesatuan pengetahuan.
\end{abstract}

Kata Kunci: UIN Raden Fatah, Epistemolgi Sains, dan Revolusi Indystri 4.0

Author correspondence

Email: ahmadzainuri_uin@radenfatah.ac.id,kabukhori@yahoo.com

_Available online at http://journal.iaingorontalo.ac.id/index.php/au/index 


\section{A. Pendahuluan}

Abuddin Nata mengatakan bahwa ada beberapa hal yang melatarbelakangi perlunya konversi IAIN menjadi UIN. Pertama, di madrasah sudah terdapat mata pelajaran umum yang dimuat dalam kurikulumnya. Ini berbeda dengan kondisi IAIN yang masih menyediakan sekolah agama. Lulusan madrasah akan merasa kesulitan untuk masuk UIN. Di samping itu konversi ini juga untuk menyambut tamatan sekolah menengah umum dapat masuk IAIN apabila telah menjadi UIN, karena dapat menyediakan jurusan dan fakultas umum. Perubahan ini juga merupakan misi untuk pemberdayaan masyarakat/umat di masa depan ${ }^{1}$.

Kedua, adanya dikhotomi ilmu-ilmu agama dan ilmu-ilmu umum. Masalah dikotomi ini solusinya adalah program integrasi ilmu pengetahuan antara ilmu agama dan ilmu umum. Dengan anggapan bahwa kalau IAIN hanya menyelenggarakan ilmu-ilmu agama. Ini akan melestarikan dikgotomi tersebut, ${ }^{2}$ maka dengan ini IAIN harus menjadi UIN untuk dapat mendirikan fakultas-fakultas umum.

Ketiga, perubahan IAIN menjadi UIN merupakan peluang bagi para lulusan untuk memasuki lapangan kerja yang lebih luas ${ }^{3}$. Selama ini, arah lulusan IAIN adalah lembaga pendidikan Islam, kegiatan kegiatan keagamaan, dakwah dan pada tataran departemen agama. Mmaka dengan perubahan menjadi UIN akan lebih meluas lingkup kerja dan eksistensi lulusan IAIN. Dengan perubahan menjadi UIN juga sebagai upaya konvergensi ilmu umum dan agama, seperti yang diungkapkan oleh Harun Nasution bahwa perubahan IAIN menjadi universitas dirancang untuk menghilangkan dikotomi ilmu pengetahuan ${ }^{4}$.

Keempat, perubahan IAIN menjadi UIN adalah dalam rangka memberikan peluang bagi lulusan IAIN untk melakukan mobilitas vertikal. Yakni, kesempatan gerak dan peran dan memasuki medan yang lebih luas. Lulusan IAIN akan

\footnotetext{
${ }^{1}$ Abuddin Nata, Manajemen Pendidikan, 5th ed. (Jakarta: Kencana Prenada Media Group, 2010), 56.

${ }^{2}$ Nata, Manajemen Pendidikan.

${ }^{3}$ Nata.

${ }^{4}$ Kusmana and Yudi Munadi, Proses Perubahan IAIN Menjadi UIN Syarif Hidayatullah Jakarta (Jakarta: UIN Jakarta Press, 2002), 28.
} 
memasuki wilayah dan lingkungan yang lebih luaus, bervariasi dan bergengsi. Perubahan ini juga ingin kembali menaruh harapan umat Islam menjadi pelopor peradaban manusia yng dulu pernah dicapai Islam zaman klasik ${ }^{5}$.

Kelima, perubahan IAIN menjadi UIN juga merupakan tuntutan akan penyelenggaraan pendidikan yang professional, berkualitas tinggi dan menawarkan banyak pilihan. Apalagi dengan sambutan arus globalisasi yang melahirkan lingkungan persaingan dan kompetisi. Sehingga IAIN dengan menjadi UIN merupakan bagian dari upaya menghadapi tantangan dan menangkap peluang.

Selanjutnya, Abuddin Nata menambahkan ada beberapa permasalahan yang muncul baik itu terkait dengan legal formal, kelembagaan, filosofis, histori, psikologis dan bahkan politis ${ }^{6}$. Ia menjelaskan bahwa dari segi legalitas, penambahan fakultas-fakultas umum atau non agama akan terbendung dengan PP No. 60 Tahun 1999, ada yang ditekankan dalam peraturan tersebut yakni institut. Istititut yang dijelaskan dalam peraturan tersebut adalah lembaga pendidikan tinggi yang menyelenggarakan pendidikan dalam satu kelompok bidang Studi tertentu, seperti kelompok bidang Studi agama saja, hukum saja, pertanian saja dan seterusnya. Masalah berikutnya adalah kelembagaan, setelah perubahan IAIN menjadi Universitas apakah kelembagaannya berada di bawah naungan departemen Agama atau berada di bawah Departemen Pendidikan Nasional. Persoalan lain yang muncul adalah latar belakang filosofis-historis. Di mana IAIN memiliki akar filosofis visi dakwah dan pengkajian keislaman. Adanya kekhawatiran tokoh Islam akan dihapuskannya hasil perjuangan pendahulu mereka atas IAIN. Sisi lain juga ada masalah yang timbul dengan perubahan IAIN menjadi UIN yakni masalah yang bersifat politik. Di mana berdirinya IAIN tidak terlepas dari bentuk akomodir dan penghargaan pemerintah atas peran dan kontribusi umat Islam dalam perjuangan bangsa ini ${ }^{7}$.

\footnotetext{
${ }^{5}$ Nata, Manajemen Pendidikan, 6.

${ }^{6}$ Nata, 62.

${ }^{7}$ Nata, 64.
} 
Bila berpijak pada pandangan Azyumardi Azra bahwa gagasan dan konsep dasar pengembangan IAIN menuju UIN tak lepas dari beberapa masalah yang dihadapi IAIN dalam perkembangannya selama ini. Pertama, IAIN belum berperan secara optimal dalam dunia akademik, birokrasi dan masyarakat Indonesia secara keseluruhan. IAIN lebih banyak berperan di masyarakat karena dalam konteks dakwah. Kedua, kurikulum IAIN belum mampu merespon perkembangan Iptek dan perubahan masyarakat yang semakin kompleks ${ }^{8}$. Kendati demikian, perubahan status dari IAIN ke UIN telah menimbulkan banyak problem epistemologis. Problem tersebut bermuara pada adanya dikotomi ilmu antara ilmu agama di satu pihak dan ilmu umum di pihak lain. Untuk menghilangkan problem dikotomis tersebut, UIN Jakarta perlu menerapkan dan mengembangkan epistemologis yang Islami dan terpadu.

Hal itu sejalan dengan pendapat Mulyadhi Kartanegara dalam Diskusi Pakar tentang "Krisis Epistemologis Islam di Perguruan Tinggi" di Ruang Diorama, Jumat (23/5) ketika menyoroti konversi UIN Jakarta diungkapkan bahwa UIN Jakarta perlu menerapkan epistemologi Islam dan terpadu karena perguruan tinggi ini dinilai masih lemah dari sisi epistemologi. Sehingga integrasi ilmu yang diharapkan akan mampu memberikan nuansa berbeda dengan perguruan tinggi Islam lain dapat tercapai. "Dari awal sebetulnya saya sudah memberikan pandangan mengenai bangunan epistemologi yang akan diterapkan di UIN Jakarta. Bahkan, untuk memberikan ke arah tersebut, saya pun menulis buku mengenai integrasi ilmu," kata Mulyadhi, yang juga Direktur CIPSI ini ${ }^{9}$.

Jadi, dapat ditegaskan di sini bahwa tanpa bermaksud mengesampingkan sarana fisik lainnya, perubahan paradigma dan struktur bangunan keilmuan di UIN menjadi sangat penting. Apalagi bila dikaitkan dengan perkembangan konsep keilmuan saat ini. Selama ini disinyalir bahwa perkembangan ilmu pengetahuan dan teknologi secara faktual tidak berkorelasi positif terhadap kesejahteraan umat manusia.

\footnotetext{
${ }^{8}$ Nata, 23.

9 "UIN Jakarta Perlu Terapkan Epistemologi Islam Terpadu," UIN Syarif Hidayatullah Jakarta Official Website, accessed December 19, 2019, https://www.uinjkt.ac.id/id/uin-jakarta-perlu-terapkanepistemologi-islam-terpadu/.
} 
Problem krusial yang dihadapi dalam epistemologi keilmuan ini karena masih terjadinya dikhotomi, yang membedakan antara ilmu agama dan ilmu umum. Padahal, menurut Mulyadhi, hal itu sebetulnya tak perlu terjadi karena dalam konsep Islam tidak ada dikhotomi. "Barat memang masih memandang bahwa sains modern hanya mengakui obyek-obyek empiris dan menolak semua entitas non-fisik sebagai obyek sah ilmu pengtetahuan. Tapi dalam tradisi ilmiah Islam, bukan hanya obyek-obyek empiris yang diakui ontologisnya, tetapi juga obyek-obyek non-empiris, sehingga sebuah sistem epistemologi yang integral sangat mungkin dibangun ${ }^{10}$.

Dalam konteks inilah penelitian ini akan memfokuskan pembahasan mengenai bagaimana konversi IAIN menjadi UIN di era globalisasi dalam perspektif epistemologi sains, khususnya berkaitan dengan desain kurikulum di UIN Raden Fatah Palembang. Hal ini penting, sebab seperti disinggung di atas, permasalahan mendasar konversi IAIN menjadi UIN tidak terbatas pada problem tenaga pengajar, fasilitas dan sarana, dan dana. Tetapi tak kalah pentingya adalah masalah konsep keilmuan atau landasan epistemologis sains yang selama ini masih "dianggap dikhotomis". Dengan adanya konversi ini setidaknya berupaya untuk menghilangkan atau paling tidak mereduksi dikhotomi ilmu pengetahuan yang selama ini menghinggapi sebagian besar kaum Muslimin.

Konversi IAIN menjadi UIN dalam kajian epistemologi, dalam artian integrasi ilmu agama dan ilmu umum, sudah selayaknya menjadi core curriculum dari transformasi kelembagaan dari IAIN menjadu UIN dengan konsep pohon ilmu yang digagas Imam Suprayogo. Konsep pohon ilmu ini menjadi flosofis, bahkan menjadi branding UIN, khususnya dalam mendesain kurikulum Program Magister Studi Islam Pascasarjana UIN Raden Fatah Palembang dalam rangka mempersiapkan SDM yang berkualitas, sehingga mampu bersaing di era era Revolusi Industri 4.0 saat ini. Atas dasar pemikiran inilah fokus permasalahan dalam penelitian ini adalah bagaimana konversi IAIN menjadi UIN di era globalisasi perspektif epistemologi sains, suatu analisis desain kurikulum UIN Raden Fatah Palembang?

10 "UIN Jakarta Perlu Terapkan Epistemologi Islam Terpadu." 


\section{B. Metode Penelitian}

Penelitian ini dilaksanakan di UIN Raden Fatah Palembang karena itu penelitian ini bersifat lapangan (field research) dan juga bersifat penelitian deskriptif. Ada dua jenis sumber data, yaitu sumber data primer diperoleh langsung dari informan di lapangan mulai dari rektor, wakil rektor bidang akademik, dekan fakultas, sekretaris jurusan, direktur, ketua program studi magister dan doktor di lingkungan UIN Raden Fatah dan pemangku kebijakan lainnya yang dijaring melalui teknik snowball. Sedangkan data sekunder, baik berupa hasil penelitian, jurnal ilmiah, buku, dan lainnya. Teknik pemeriksaan keabsahan data penelitian ini menggunakan teknik triangulasi ${ }^{11}$ dan analisis isi (content analysis) ${ }^{12}$ erat hubungannya dengan teori hermeneutika dikembangkan oleh Hans-Georg Gadamer.

\section{Paradigma Epistemologi Sains Dalam al-Qur'an}

Secara sederhana, epistemologi dapat diartikan teori pengetahuan. Ketika mengkaji bidang ini, maka ada tiga persoalan pokok yang perlu dibahas, yaitu makna pengetahuan, sumber pengetahuan, genealogi pengetahuan, bagaimana cara mengetahuinya, dan apakah pengetahuan kita itu benar (valid) ${ }^{13}$ Objek telaah epistemologi adalah mempertanyakan dari mana ilmu itu diperoleh, bagaimana cara mengetahuinya, bagaimana membedakan dengan yang lain, jadi berkenaan dengan situasi dan kondisi ruang serta waktu mengenai sesuatu hal ${ }^{14}$.

Konsep epistemologi di atas dapat digunakan sebagai kerangka untuk menggali epistemologi ilmu menurut al-Qur'an, sehingga muncul pertanyaan tentang apa pengertian ilmu menurut al-Qur'an?, apa sumber ilmu pengetahuan menurut al-Qur'an?, dan bagaimana cara mengetahuinya atau bagaimana metode mendapatkan ilmu menurut al-Qur'an?

\footnotetext{
${ }^{11}$ Lexy. J Moeleong, Metodologi Penelitian Kualitatif. (Bandung: Remaja Rosdakarya, 2000), 178.

${ }^{12}$ Fred N Kerlinger, Foundations of Behavioral Research: Educational and Psychological Inquiry. (New York: Holt, Rinehart and Winston, 1965), 525.

${ }^{13}$ Juhaya S Praja, “Aliran-Aliran Filsafat Dan Etika,” Jakarta: Prenada Media, 2003, 16.

${ }^{14}$ Inu Kencana Syafiie, "Pengantar Filsafat," Bandung: PT. Refika Aditama, 2004, 10.
} 
a) Ilmu Menurut al-Qur'an

Dalam al-Qur'an kata ilmu disebut sebanyak 105 kali, tetapi jika digabung dengan kata derivasinya ia disebut tidak kurang dari 744 kali. Untuk menyebutkan secara terinci, kata-kata turunan itu disebut dalam bentuk dan frekuensi sebagai berikut; 'alima (35), ya'lam (215), i'lam (31), yu'lam (1), 'ilm (105), 'alim (18), ma'lum (13), 'alamin (73), 'alam (3), 'alam (49), 'alim/'ulama' (163) 'allam (4)'allama (12), yu'alim (16),'ulima (3), mu'allam (1), ta'allama (2). Dari kata turunan itu timbul berbagai pengertian, seperti; mengetahui, pengetahuan, orang yang berpengetahuan, yang tahu, terpelajar, paling mengetahui, memahami, mengetahui segala sesuatu, lebih tahu, sangat mengetahui, cerdik, mengajar, belajar, orang yang menerima pelajaran/diajari, mempelajari; juga pengertianpengertian seperti tanda ('alam), alamat, tanda batas, tanda peringatan, segala kejadian alam, segala yang ada dan segala yang dapat diketahui ${ }^{15}$.

Untuk mengetahui dan menemukan pengertian tentang ilmu dalam al-Qur'an tidak cukup hanya jika dicari pengertiannya dari kata-kata yang berasal dari akar kata 'alima (tahu), sebab kata 'alima (tahu) tidak hanya diwakili oleh kata tersebut. Ada beberapa kata yang mengandung pengertian "tahu" seperti 'arafa, zahara, khabara, sha'ara, ya'isa, ankara,basirah dan hakim. Kata-kata turunan dalam alQur'an yang berasal dari kata 'arafa sendiri, umpamanya, disebut sebanyak 34 kali. Karena itu, menurut Rosenthal, kata ilmu adalah sinonim dengan kata ma'rifat ${ }^{16}$.

Salah satu kata derivasinya juga telah menjadi bahasa Indonesia yang kita kenal, yaitu 'arif. Kata ini memang diartikan sebagai orang yang memiliki pengetahuan yang tertinggi (QS al-Maidah: 83), jika orang telah sampai kepada tahap ma'rifat yang lebih dikenal di dunia tasawuf.

Pengertian ilmu pengetahuan terdapat pula dalam kata "hikmah" yang sudah menjadi kata Indonesia. Kata "hikmah" biasanya dipakai langsung tanpa

\footnotetext{
${ }^{15}$ M Dawam Rahardjo and Budhy Munawar Rachman, Ensiklopedi Al-Qur'an: Tafsir Sosial Berdasarkan Konsep-Konsep Kunci (Diterbitkan oleh Penerbit Paramadina bekerjasama Jurnal Ulumul Qur'an, 1996), 531.

${ }^{16}$ Rahardjo and Rachman, 532.
} 
terjemahan, dan pengertiannya adalah "pelajaran". Orang yang bisa memetik "hikmah" adalah orang yang dapat "mengambil pelajaran" dari pengalaman. Tetapi "hikmah" dapat pula diterjemahkan dengan "kebijaksanaan", atau pengetahuan tertinggi (wisdm). Dalam al-Qur'an kata "hikmah" memang berkaitan dengan hasil pemikiran. Hikmah merupakan sesuatu yang sangat berharga (QS. alBaqarah:269).

Berdasarkan penjelasan di atas dapat ditegaskan bahwa al-Qur'an menggunakan kata ilmu dalam berbagai bentuk dan artinya sebanyak 854 kali, antara lain, sebagai proses pencapaian ilmu pengetahuan dan objek ilmu pengetahuan (QS al-Baqarah: 31-32) tentang sumber-sumber ilmu pengetahuan, di samping klasifikasi dan ragam disiplinnya. Sehingga sebagian ilmuwan muslim berpendapat bahwa ilmu menurut al-Qur'an mencakup segala macam pengetahuan yang berguna bagi manusia dalam kehidupannya, baik masa kini maupun masa depan, baik tentang ilmu-ilmu fisika (empirik) maupun metafisika (non empirik) ${ }^{17}$.

\section{b) Sumber Ilmu Pengetahuan Menurut al-Qur'an}

Dalam kaitan ini, ayat-ayat al-Qur'an sebenarnya telah mengisyaratkan bahwa pengetahuan dapat diperoleh manusia setidaknya dari tiga sumber, yaitu: Pertama, alam jagat raya ini, yakni semua realitas yang ada di jagat alam semestamerupakan sumber pengetahuan bagi manusia. Pengetahuan tentang realitas alam raya ini dapat dikatakan sebagai pengetahuan empiris (bandingkan dengan aliran empirisme). Kedua, akal pemikiran manusia sendiri, yakni dengan menafsirkan danmengembangkan fenomena alam itu menjadi rumusan-rumusan teori ilmu pengetahuan yang berguna bagi manusia. Pengetahuan yang bersumber dari akal ini dapat disebut sebagai pengetahuan rasional (bandingkan dengan aliran rasionalisme), dan sekaligus sebagai pengetahuan fenomenologis (bandingkan dengan aliran fenomenalisme).Ketiga, sumber pengetahuan yang berasal dari wahyu, yaitu pengetahuan yang diturunkan langsung oleh Allah Ta'ala

\footnotetext{
${ }^{17}$ M Quraish Shihab, “Membumikan” Al-Quran: Fungsi Dan Peran Wahyu Dalam Kehidupan Masyarakat (Mizan Pustaka, 2007).62
} 
Integration of Interdisciplinary scientific in the Curriculum at UIN Raden Fatah Palembang

melalui para nabi dan rasul-Nya serta kesaksian orang-orang shalih yang menjadi para pengikut setianya. .

Dalil-dalil al-Qur'an yang menunjukkan isyarat tentang ketiga sumber ilmu pengetahuan itu adalah;

a) Empiris, yakni alam sebagai sumber ilmu pengetahuan, antara lain, dapat ditangkap dari beberapa isyarat ayat al-Qur'an, seperti Allah mengajarkan nama-nama benda kepada Adam As, perintah Allah untuk memperhatikan dan mempelajari fenomena yang terjadi pada benda-benda langit, dan fenomenafenomena yang terjadi di bumi, meneliti dan mempelajari awan, gununggunug, lautan dan mahluk hidup yang ada di bumi, dan lain sebagainya $(Q S$ alBaqarah: 31; QS. Yunus: 101; QS. al-Ghasiyah: 20; dan QS. al-Nahl: 88).

b) Rasio, yakni akal sebagai sumber ilmu pengetahuan dengan menafsirkan dan mengabstraksikan fenomena alam itu menjadi rumusan-rumusan teori ilmu pengetahuan yang berguna bagi manusia (QSal-Hadid: 17; QS. al-Mu'minun: 67; QS. al-Dhariyat: 21; dan QS. al-Saffar: 137).

c) Intuisi dan wahyu sebagai sumber ilmu pengetahuan, yakni pengetahuan yang diturunkan Tuhan melalui para nabi dan rasul-Nya, termasuk dalam kategori ini adalahpengetahuan tasawuf dan filsafat yang diperoleh melalui intuisi dan hasil kontemplasi pemikiran (QS al-Syura: 13, 52 dan 63)..

Berkaitan dengan hal di atas, menarik mengutip pendapat Abdul Fattah Jalal yang mengatakan bahwa sumber ilmu pengetahuan terbagi atas dua macam, yaitu; Basyariyyah (sumber manusiawi) dan Ilahiyah (sumber Ilahi). Kedua macam sumber ilmu pengetahuan ini akhirnya kembali kepada Allah Swt ${ }^{18}$. Yang pertama, yakni sumber manusiawi (basyariyyah) dapat dicapai manusia melalui berbagai jalan. Di antaranya, peniruan (taklid), seperti peristiwa pemakaman putra Adam As (QS. al-Maidah: 31). Selain peniruan, ilmu pengetahuan dapat dicapai manusia melalui trial and error dan pengalaman (empiris). Sedangkan yang kedua, yakni sumber Ilahiyah yang berasal dari Allah Swt. Yang dimaksud dengan pengetahuan di sini adalah ilmu syariat maupun ilmu ad-Din yang dipelajari oleh manusia

\footnotetext{
${ }^{18}$ Abdul Fattah Jalal, “Azas-Azas Pendidikan Islam,” Cet. I, Bandung: Diponegoro, 1988, 143.
} 
melalui wahyu (kitab suci al-Qur'an) yang diturunkan oleh Allah kepada para Rasul-Nya ${ }^{19}$.

Pendapat Abdul Fattah Jalal di atas dapat dipahami bahwa ilmu pengetahuan yang diserap manusia melalui dua sumber; sumber Ilahi dan sumber manusiawi. Ilmu pengetahuan yang diraih manusia melalui apa yang diwahyukan kepada rasul, lalu dipikirkan dan diimani. Sedangkan ilmu pengetahuan yang bersumber dari manusiawi dapat dicapai melalui peniruan, penggunaan akal pikiran, pengalaman dan sebagainya. Tapi, kedua sumber ilmu pengetahuan ini pada akhirnya bermuara pada satu sumber, yakni Allah Swt, Yang Maha Mengetahui.

\section{c) Metode memperoleh ilmu}

Berkenaan dengan metode atau cara memperoleh ilmu pengetahuan, alQur'an mengisyaratkan melalui beberapa metode, yaitu; Pertama, ilmu diperoleh manusia melalui tanggapan indrawi (al-hissi) atau dapatjuga dikatakan melalui pengalaman empirik (al-tajribah) (QS al-Nahl: 78; QS. Bani Israil: 36; QS. alMu'minun: 78; QS. al-Shajadah: 9, dan QS. al-Mulk: 23). Kedua, metode bayani (analisis kebahasaan). Metode ini diperkenalkan oleh Muhammad 'Abid al-Jabiri. Menurutnya, pemahaman analisis terhadap nash dan pengambilan konsep-konsep pemikiran dari nash-nash tersebut dapat dilakukan melalui pendekatan bayani, burhani dan 'irfani. Ketiga, cara mendapatkan pengetahuan melalui analisis pemikiran logis dan rasional (nazariyah 'aqliyah) atau dengan istilah yang populer disebut metode burhani. Keempat, pengetahuan dapat diperoleh manusia melalui intuisi dan kontemplasi atau ma'rifat al-qalb setelah melewati proses riyadah dan mujahadah, sehingga terjadi mukashafah, atau yang lebih dikenal dengan metode 'irfani. Kelima, pengetahuan diperoleh melalui wahyu dan kesaksian langsung (shahadah)orang-orang terpercaya atas diturunkannya wayu kepada nabi dan rasul Allah Swt, atau dikenal dengan metode al-matlu (QS al-Syura: 13, 52 dan 63).

${ }^{19}$ Jalal, 150. 
Mencermati penjelasan di atas dapat disimpulkan bahwa secara dalam perspektif al-Qur'an tidak ada dikhotomi konsep keilmuan, tidak ada pemisahan antara satu disiplin keilmuan dengan disiplin keilmuan lainnya. Semuanya berjalan menurut konteksnya dan saling melengkapi satu sama lain dan memberi manfaat dalam kehidupan manusia. Kalau ditinjau historisitasnya, konsep integrasi keilmuan bukanlah barang baru, karena telah didiskusikan oleh ulama-ulama klasik Islam. Sebagai contoh, al-Syafi'i dalam karya monumentalnya al-Umm, mendasari uraian master piece-nya itu dengan memposisikan al-Qur'an dan hadits sebagai sumber utama keilmuan. Kedua pedoman tersebut menetapkan prinsip dasar dan petunjuk bagi manusia untuk meraih kebahagiaan hidup di dunia dan akhirat.

Imam Suprayogo juga mendefinisikan integrasi keilmuan sebagai pemposisian al-Qur'an dan hadits sebagai grand theory bagi pengetahuan (Suprayogo, dalam Zainal Abidin Bagir (ed), 2005: 49-50). Dengan begitu, argumentasi naqli tersebut dapat terpadukan dengan temuan ilmu. Lahirnya konsep integrasi dilatari oleh dikotomi antara ilmu-ilmu agama dan ilmu-ilmu umum. Keduanya terpisahkan dan seolah berjalan pada wilayah arsirannya masing-masing. Ia juga dipicu oleh separasi antara sistem pendidikan Islam dan sistem pendidikan modern yang berdampak laten bagi umat Islam. Asumsi yang berkembang adalah "ilmu tidak peduli dengan agama, begitupun (sebaliknya) agama abai terhadap ilmu”. Hal ini juga berimplikasi pada berkembangnya slogan "ilmu untuk ilmu", yang acapkali menapikan nilai etika dalam implementasinya. Ilmu dan agama seolah dua entitas yang berlainan dan terpisah satu sama lain, mempunyai wilayah masing-masing, baik objek formal--material keilmuan, metode penelitian, kriteria kebenaran, peran yang dimainkan oleh ilmuwan, bahkan ke tingkat institusi penyelenggaranya $^{20}$.

\footnotetext{
${ }^{20}$ M Amin Abdullah, Islamic Studies Di Perguruan Tinggi: Pendekatan Integratif-Interkonektif (Pustaka Pelajar, 2006), 92.
} 


\section{Analisis Paradigma Epistemologi Sains Dalam Desain Kurikulum UIN Raden Fatah Palembang}

Sementara itu, di UIN Raden Fatah Palembang integrasi ilmu telah menjadi alasan keberadaan (raison d'etre) lembaga pendidikan tinggi Islam ini. Semua UIN Raden Fatah telah mengemban mandat negara untuk mempelopori atau mendorong terwujudnya integrasi ilmu-ilmu keagamaan dan ilmu-ilmu nonkeagamaan, sehingga melahirkan body of knowledge yang kokoh dan holistik, yang merefleksikan sebuah tradisi keilmuan ala Indonesia yang tidak sekuler dan membumi.

Untuk itu salah satu tugas penting yang harus dilakukan oleh UIN Raden Fatah ke depan adalah menyusun konsep dasar (basic concept) dan peta jalan (road map) menuju integrasi ilmu, yang dapat dijadikan panduan bagi para anggota sivitas akademika di semua fakultas dan program studi. Di sinilah kita melihat bahwa UIN Raden Fatah Palembang menggunakan kurikulum yang mengacu kepada Kerangka Kualifikasi Nasional Indonesia (KKNI). Model kurikulum ini sangat ideal untuk diimplementasikan karena dapat menyandingkan, menyetarakan, dan mengintegrasikan antara bidang pendidikan dan bidang pelatihan kerja serta pengalaman kerja dalam rangka pemberian pengakuan kompetensi kerja sesuai dengan struktur pekerjaan di berbagai sektor.

Berdasarkan pernyataan narasumber dalam penelitian ini disimpulkan bahwa memang UIN Raden Fatah sudah memiliki kerangka dasar integrasi epistemologis sains dengan adanya "rumah ilmu". Seperti, dalam kurikulum, mata kuliah yang terkait dengan hukum keluarga Islam di integrasi-interkonesikan dengan hukum keluarga umum, terutama hukum yang berlaku di Indonesia, sehingga diharapkan mahasiswa menguasai hukum positif di Indonesia.

Demikian pula, untuk meningkatkan daya saing lulusan, kurikulum UIN Raden Fatah telah dilakukan integrasi-interkonesi dengan penguatan pengetahuan dan ketrampilan keagamaan melalui program intensif baca-tulis al-Qur'an (tahsinul qira'ah, tahsinul khat) dan pelatihan ketrampilan keagamaan. Peningkatan pengetahuan dan ketrampilan bahasa asing, khususnya Bahasa Arab 
dan Inggris, melalui program pelatihan bahasa secara intensif. Di samping itu, pengembangan pendidikan karakter melalui semua kegiatan Tri Dharma dan penanaman nilai-nilai kewirausahaan (enterpreneurship) dan pemberian ketrampilan hidup (life skills). Sehingga akan menghasilkan lulusan yang berilmu pengetahuan (ulul ilmi) dan sekaligus sosok yang cendekia (ulul albab) yang mapan secara ekonomis (ulul amwal).

Meskipun secara konseptual, UIN Raden Fatah telah memiliki "rumah ilmu" sebagai kerangka dasar integrasi epistemologis sains, tetapi belum diuji secara akademik dan tersosialisasi secara massif. Teruji secara akademik, khusus dikaji dari aspek epistemolgi sains, ini menjadi sangat penting untuk melihat keunngulan dan kelemahannya.

Kajian "rumah ilmu" dalam perspektif teori hermeneutika Hans-Georg Gadamer, tidak terlepas dari epistemologi sains sebagai salah satu kajian filsafat ilmu, di mana didalamnya terjadi perubahan paradigma keilmuan dapat dilakukan dengan cara menginterpretasikan kerangka filosofis keilmuan yang menjadi dasar pijakan keilmuan UIN. Tak kalah pentingnya dengan kerangka teori hermeneutika Gadamer yang mengkaji epistemologi sains sebagai bagian yang tak terpisahkan dalam konteks relevansinya dengan al-Qur'an, sehingga dapat dirumuskan relevansi kandungan ayat-ayat al-Qur'an dengan ilmu pengetahuan yang berkembang saat ini.

Dalam kerangka teori hermeneutika Gadamer bahwa pandangan hidup Islam bersumber kepada wahyu yang didukung oleh akal dan intuisi. Substansi agama, seperti keimanan, dan pengalamannya, ibadah, doktrin serta sistem teologinya telah ada dalam wahyu dan dijelaskan oleh Nabi (Adnin Armas, 2005: 14). Dalam kaitan inilah, integrasi epsitemolgi sains atau dalam bahasa al-Attas, disebut Islamisasi pada dasarnya pembebasan manusia dari tradisi magis, mitologis, animistis, nasional-kultural, dan sesudah itu dari pengendalian sekular terhadap nalar dan bahasanya. Ini artinya integrasi epsitemologi sains (Islamisasi ilmu) berarti pembebasan ilmu dari penafsiran-penafsiran yang didasarkan pada 
ideologi sekuler, dan dari makna-makna serta ungkapan manusia-manusia sekuler 21.

Sementara itu, Isma'il Raj'i al-Faruqi meletakkan fondasi epistemologi sainsnya pada prinsip tauhid yang terdiri dari lima kesatuan, yaitu; 1. Keesaan (kesatuan) Allah; 2. Kesatuan Alam Semesta; 3. Kesatuan Kebenaran dan Kesatuan Pengetahuan; 4. Kesatuan hidup; dan 5. Kesatuan manusia. Untuk merealisasikan tujuan-tujuan ini, sejumlah langah harus diambil menurut suatu urutan logis yang menentukan prioritas-prioritas masing-masing langkah tersebut. Adapun langkah kerja integrasi epistemologi sains yang dirumuskan al-Faruqi, sebagai berikut; 1 . Penguasaan Disiplin Ilmu Modern: Penguraian Kategoris; 2. Survei Disiplin Ilmu; 3. Penguasaan Khasanah Islam: Sebuah Antologi; 4. Penguasaan Khasanah Ilmiah Islam Tahap Analisa; 5. Penentuan Relevansi Islam yang Khas Terhadap Disiplindisiplin Ilmu; 6. Penilaian Kritis Terhadap Disiplin Ilmu Modern: Tingkat Perkembangannya di Masa Kini; 7. Penilaian Kritis Terhadap Khasanah Islam: Tingkat Perkembangannya Dewasa Ini; 8. Survei Permasalahan yang Dihadapi Umat Manusia; 9. Survei Permasalahan yang Dihadapi Manusia; 10. Analisis Sintesis Kreatif dan Sintesis; 11. Penuangan Kembali Disiplin Ilmu Modern ke dalam Kerangka Islam: Buku-buku Daras Tingkat Universitas; dan 12. Penyebarluasan Ilmu-ilmu yang Telah Diislamisasikan ${ }^{22}$.

Namun konsep integrasi epistemologi sains yang dikemukakan al-Faruqi mendapat kritik dari Ziauddin Sardar. Kritik Sardar diarahkan pada pendapat adanya relevansi antara ilmu pengetahuan Islam dan ilmu pengetahuan Barat. Ia tidak setuju dengan al-Faruqi yang menyatakan perlunya penguasaan terhadap ilmu pengetahuan Barat terlebih dahulu untuk menguasai ilmu pengetahuan Islam. Sardar menjelaskan bahwa semua ilmu dilahirkan dari pandangan tertentu dan dari segi hierarki tunduk kepada pandangan tersebut. Sardar menekankan perlunya penciptaan suatu ilmu pengetahuan Islam kontemporer sebagai counter atas ilmu pengetahuan modern Barat.

\footnotetext{
${ }^{21}$ Syed Muhammad Al-Naquib Al Attas, Haidar Bagir, and Jalaluddin Rahmat, Konsep Pendidikan Dalam Islam (Mizan, 1984), 90.

${ }^{22}$ Isma'il R Al-Faruqi, International Institute of Islamic Thought, and Seminar on "Islamization of Knowledge," Islamization of Knowledge: General Principles and Work Plan (Herndon, VA: International Institute of Islamic Thought, 1987), 99-107.
} 
Integration of Interdisciplinary scientific in the Curriculum at UIN Raden Fatah Palembang

Dilihat dari perspektif hermeneutik dapat dikatakan bahwa visi pemikiran Sardar terletak pada cara ia memandang Islam. Berbeda dengan para intelektual muslim sebelumnya (al-Attas dan al-Faruqi) yang melihat Islam secara atomistik. Sardar memahami Islam sebagai sebuah "peradaban" utuh yang harus direkonstruksi. Para intelektual muslim tradisional melihat Islam hanya sekedar tuntunan perilaku dalam kehidupan sosial, ekonomi, pendidikan, dan politik. Sedangkan para intelektual muslim modern lebih membatasi Islam sebagai kesalehan pribadi, keyakinan-keyakinan, dan ritual-ritual. Baik para intelektual muslim tradisional maupun modern hanya melihat Islam sebagai wawasan keagamaan yang tidak mampu memunculkan dirinya sebagai sebuah peradaban ${ }^{23}$.

Bila diinterpretasikan pemikiran Sardar dapat dipahami bahwa Sardar menyebutkan setidaknya terdapat tujuh tantangan besar yang harus dihadapi oleh umat Islam saat ini. Sardar mengharuskan elaborasi lebih jauh atas tantangantantangan tersebut sebagai prasyarat pokok untuk rekonstruksi peradaban Islam. Tujuh tantangan tersebut adalah: (1) pandangan-dunia Islam, (2) epistemologi Islam, (3) syariah, (4) struktur sosial dan politik, (5) kegiatan ekonomi, (6) sains dan teknologi, (7) lingkungan hidup. Di luar tujuh tantangan tersebut, masih ada lagi hal-hal yang juga penting untuk dikaji, namun sifatnya sekunder, seperti arsitektur, kesenian, pendidikan, perkembangan komunitas, dan perilaku sosial ${ }^{24}$.

Dari sudut pandangan hermeneutika, tampaknya Sardar ingin melakukan telaah terhadap konsep integrasi epistemologi sains al-Faruqi di dalam tiga aspek, yakni; kritik paradigma, kritik epistemologi, dan kritik metodologi. Sebagaimana diketahui, dalam konsepnya al-Faruqi hendak melakukan islamisasi ilmu pengetahuan (integrasi epistemologi sains), yaitu ilmu ilmu sosial Barat; ilmu ekonomi, ilmu politik, sosiologi, psikologi, dan antropologi. Islamisasi yang dimaksud yaitu menanamkan spirit Islam pada disiplin ilmu sosial Barat ${ }^{25}$.

\footnotetext{
${ }^{23}$ Ziauddin Sardar and A. E. Priyono, Jihad intelektual : merumuskan parameter-parameter sains Islam (Surabaya: Risalah Gusti, 2000), 1.

24 Sardar and Priyono, 8-9.

${ }^{25}$ Sardar and Priyono, 50.
} 


\section{E. Kesiapan UIN Raden Fatah Palembang Menghadapi Era Revolusi Industri} 4.0.

Sejalan dengan visi UIN Raden Fatah adalah menjadikan UIN sebagai lembaga pendidikan "internasionalisasi" tentunya menuntut seluruh sivitas akademika UIN Raden Fatah untuk mampu membangun jaringan internasional (international networking) serta mengembangkan kegiatan bertaraf internasional (international programs), memiliki kapasitas untuk melayani mahasiswa internasional (a capacity to serve international stuidents) dan mengukir prestasi bertaraf internasional (international reputation), yang menembus batas-batas kenegaraan (crossing [national] borders). Karena sesuai standar internasional, Quacquarelli Symonds (QS), lembaga riset yang bergerak di bidang pendidikan tinggi dalam rilisnya pada 2010 menyebutkan bahwa ada beberapa kriteria inti harus dipenuhi perguruan tinggi, di antaranya; pertama, kualitas penelitian, kedua, lulusan kerja, ketiga, kualitas pengajaran, dan keempat, infrastruktur

Visi ini haruslah didukung oleh integrasi epistemologi sains. Melihat kenyataan yang ada memang sudah dibuka fakultas saintek dan prodi komunikasi. Namun ke depan haruslak mensinergikan integrasi epistemologi sains dalam kurikulum pembelajaran di UIN Raden Fatah. Hal ini mengingat saat ini dunia telah memasuki era revolusi industri generasi ke empat (Revolusi Industri 4.0) yang ditandai dengan meningkatnya konektivitas, interaksi serta perkembangan sistem digital, kecerdasan artifisial, dan virtual. Dengan semakin konvergennya batas antara manusia, mesin dan sumber daya lainnya, teknologi informasi dan komunikasi tentu berimbas pula pada berbagai sektor kehidupan. Salah satunya yakni berdampak terhadap sistem pendidikan di Indonesia, terutama UIN Raden Fatah Palembang.

Revolusi Industri 4.0 yang sarat akan teknologi yang super cepat akan membawa perubahan yang cukup signifikan terhadap proses pembelajaran di UIN Raden Fatah Palembang. Perubahan dalam sistem pendidikan tentunya akan berdampak pula pada rekonstruksi kurikulum di UIN Raden Fatah, peran dosen sebagai tenaga pendidik dan pengembangan teknologi pendidikan yang berbasis ICT. Ini adalah tantangan baru untuk merevitalisasi kembali pendidikan UIN Raden 
Fatah, guna menghasilkan orang-orang cerdas, yang kreatif dan inovatif serta mampu berkompetisi secara global ${ }^{26}$.

Seperti diungkapkan Dekan Fak Saintek, Dr. Dian Erlina, S.Pd, M.Hum, dalam penerapan integrasi keilmuan, dosen-dosen UIN Raden Fatah Palembang masih pada tahap mencoba menerapkan dengan ikhtiar masing-masing karena belum adanya pedoman dan panduan yang jelas dari pihak universitas, misalnyauntuk konteks di lingkungan fakultas sains dan tekhnologi, rencana pembelajaran semester (RPS) dan bahan ajar sudah memuat integrasi keilmuan dalam muatan materi dan kegiatan pembelajaran, kegiatan penelitian dan pengembangan masyarakatjuga berbasis integrasi ilmu sehingga dapat memperkuat perpaduan dari ilmu-ilmu dasar alamiah dan sosial keagamaan yang mencirikan disingsi sains dan teknologi UIN Raden Fatah Palembang (Wawancara, 10 September 2019).

Artinya, tanpa menghilangkan jati diri UIN Raden Fatah sebagai lembaga pendidikan tinggi berciri khas "Islam". Pemanfaat dan penerapan teknologi informasi menjadi keharusan, misalnya penerapan program e-learning. Dengan penerapan e-learning akan mempermudah dan memperluas akses terhadap pendidikan, meningkatkan kesetaraan pendidikan (equity in education), akan meningkatkan mutu pembelajaran (the delivery of quality learning and teaching), meningkatkan efektifitas dan efisiensi manajemen, tata kelola, dan administrasi pendidikan.

Oleh karena itu, pengembangan desain kurikulum yang diterapkan di UIN Raden Fatah terkoneksi secara integrited ilmu pengetahuan keislaman dan umum (baca: integrasi epistemologi sains), baik pada dimensi pedagogik, keterampilan hidup, kemampuan untuk hidup bersama (kolaborasi) dan berpikir kritis dan kreatif. Hal ini tentunya dalam kerangka melahirkan out put yang mampu bersaing di era revolusi industri 4.0 yang mementingkan integrasi karakter dan keilmuanteknologi. Sebagai contoh, pembelajaran ekonomi Islam harus diintegrasikan dengan teori-teori ekonomi modern. Demikian pula, mata kuliah psikologi harus

\footnotetext{
${ }^{26}$ Delipiter Lase, Education and Industrial Revolution 4.0, 2019, 9.
} 
diintegrasikan dengan kajian disiplin keilmuan Islam dan teori-teori psikologi modern.

Selain itu, desain kurikulum UIN Raden Fatah harus mampu mengarahkan dan membentuk mahasiswa yang siap menghadapi era revolusi industri dengan penekanan pada bidang science, technology, dan mathematics (STM) yang berpijak pada integrasi epistemologi sains. Reorientasi kurikulum yang mengacu pada pembelajaran berbasis TIK, internet of things, big data dan komputerisasi, dan kewirausahaan menjadi muatan kurikulum untuk menghasilkan lulusan yang terampil di bidang literasi, literasi teknologi, dan aspek literasi manusia. Untuk memastikan kurikulum yang disesuaikan dilaksanakan secara optimal, maka kompetensi yang harus dimiliki oleh tenaga dosen sekaligus untuk memasuki era Revolusi Industri 4.0. Pertama, educational competence. Kedua, competence for technological commercialization. Ketiga, competence in globalization. Keempat, competence in future strategies. Dan, terakhir counselor competence. Selain kompetensi ini, tenaga dosen juga perlu memiliki sikap yang bersahabat dengan teknologi, kolaboratif, kreatif dan mengambil risiko, memiliki selera humor yang baik, serta mengajar secara menyeluruh (holistik).

\section{F. Kesimpulan}

Berdarkan keseluruhan uraian di atas dapat disimpulkan perubahan IAIN Raden Fatah Palembang menjadi UIN secara substansial terjadi perubahan dalam struktur bangunan keilmuan (epistemologi sains) didalamnya. Memang selama aini telah ada core curriculum bangunan integrasi epistemologi sains yang dinamakan "rumah ilmu". Konsepsi "rumah ilmu" dalam perspektif teori hermeneutika Hans-Georg Gadamer, tidak terlepas dari epistemologi sains sebagai salah satu kajian filsafat ilmu, di mana didalamnya terjadi perubahan paradigma keilmuan dapat dilakukan dengan cara menginterpretasikan kerangka filosofis keilmuan yang menjadi dasar pijakan keilmuan UIN. Tak kalah pentingnya dengan kerangka teori hermeneutika Gadamer yang mengkaji epistemologi sains sebagai bagian yang tak terpisahkan dalam konteks relevansinya dengan al-Qur'an, sehingga dapat dirumuskan relevansi kandungan ayat-ayat al-Qur'an dengan ilmu pengetahuan yang berkembang saat ini. Tetapi konsepsi "rumah ilmu" itu belum 
Integration of Interdisciplinary scientific in the Curriculum at UIN Raden Fatah Palembang

tersosialisasi secara massif. Bahkan belum teruji secara akademik dengan pendekatan islamisasi ilmu pengetahuan. Artinya, pada tataran prakteknya, banyak kalangan menilai bahwa paradigma integrasi interkoneksi yang dibangun oleh UIN Raden Fatah masih memiliki keterbatasan, karena cenderung lebih bersifat teoritis. Konsep paradigma tersebut belum dijabarkan dalam empat ranah utama sebuah kurikulum yaitu ranah filosofis, materi, metodologi dan strategi.

Dalam kaitannya dengan era Revolusi Industri 4.0 saat ini pentingnya paradigma integratif-interkonektif keilmuan di UIN Raden Fatah yang mensinergikan ilmu keislaman dan ilmu pengetahuan-teknologi dalam prinsip tauhid, sehingga membentuk Kesatuan Kebenaran dan Kesatuan Pengetahuan.

\section{Daftar Pustaka}

Abdullah, M Amin. Islamic Studies Di Perguruan Tinggi: Pendekatan IntegratifInterkonektif. Pustaka Pelajar, 2006.

Al Attas, Syed Muhammad Al-Naquib, Haidar Bagir, and Jalaluddin Rahmat. Konsep Pendidikan Dalam Islam. Mizan, 1984.

Al-Faruqi, Isma'il R, International Institute of Islamic Thought, and Seminar on "Islamization of Knowledge." Islamization of Knowledge: General Principles and Work Plan. Herndon, VA: International Institute of Islamic Thought, 1987.

Jalal, Abdul Fattah. “Azas-Azas Pendidikan Islam.” Cet. I, Bandung: Diponegoro, 1988.

Kerlinger, Fred N. Foundations of Behavioral Research: Educational and Psychological Inquiry. New York: Holt, Rinehart and Winston, 1965.

Kusmana, and Yudi Munadi. Proses Perubahan IAIN Menjadi UIN Syarif Hidayatullah Jakarta. Jakarta: UIN Jakarta Press, 2002.

Lase, Delipiter. Education and Industrial Revolution 4.0, 2019.

Moeleong, Lexy. J. Metodologi Penelitian Kualitatif. Bandung: Remaja Rosdakarya, 2000.

Nata, Abuddin. Manajemen Pendidikan. 5th ed. Jakarta: Kencana Prenada Media Group, 2010.

Praja, Juhaya S. “Aliran-Aliran Filsafat Dan Etika.” Jakarta: Prenada Media, 2003. 
Rahardjo, M Dawam, and Budhy Munawar Rachman. Ensiklopedi Al-Qur'an: Tafsir Sosial Berdasarkan Konsep-Konsep Kunci. Diterbitkan oleh Penerbit Paramadina bekerjasama Jurnal Ulumul Qur'an, 1996.

Sardar, Ziauddin, and A. E. Priyono. Jihad intelektual: merumuskan parameterparameter sains Islam. Surabaya: Risalah Gusti, 2000.

Shihab, M Quraish. “Membumikan” Al-Quran: Fungsi Dan Peran Wahyu Dalam Kehidupan Masyarakat. Mizan Pustaka, 2007.

Syafiie, Inu Kencana. “Pengantar Filsafat.” Bandung: PT. Refika Aditama, 2004.

UIN Syarif Hidayatullah Jakarta Official Website. "UIN Jakarta Perlu Terapkan Epistemologi Islam Terpadu." Accessed December 19, 2019. https://www.uinjkt.ac.id/id/uin-jakarta-perlu-terapkan-epistemologiislam-terpadu/. 